Periodica Polytechnica Architecture, 52(1), pp. 94-101, 2021

\title{
Selected Buildings in Transylvania: About Ybl Miklós' Designs
}

\author{
Mara Popescu ${ }^{1 *}$ \\ 1 Research Management Department, "Ion Mincu" University of Architecture and Urban Planning, 010014 Bucharest, \\ 18-20 Academiei Street, Romania \\ * Corresponding author, e-mail: mara.popescu@uauim.ro
}

Received: 02 July 2018, Accepted: 16 June 2021, Published online: 14 July 2021

\begin{abstract}
Ybl Miklós is a leading figure of nineteenth-century architecture, one of the prestigious Hungarian architects who won the Franz Jozef Knights' Cross and the Knight's Cross Order of Leopold medals, a member of Budapest's Board of Public Works and the Association of Architects and Engineers. His works represented highly complex national and European heritage values and were a reference point for nineteenth century Hungarian architecture. In 2014, when UNESCO celebrated the bicentennial of the birth of Ybl Miklós, it marked both his personality and the architect's vision. In his honour, the Faculty of Architecture and Civil Engineering of the Szent István University in Budapest bears his name.

Some of his works in Transylvania and the connections he had with Transylvanian nobles are lesser known. This article highlights another aspect of his work.
\end{abstract}

\section{Keywords}

Ybl Miklós, Károlyi Castle, Nagykároly, Csitó Castle, Church of Kaplony

\section{Introduction}

Miklós Ybl, or Ybl Miklós, to use the Hungarian naming convention, was the greatest Hungarian architect of the second half of the $19^{\text {th }}$ century.

He was born in 1814 in Székesfehérvár and attended the Vienna Technical Institute. In 1832, Ybl became Mihály Pollack's assistant, and after, he moved to Henrik Koch's office for four years between 1836 and 1840. He then moved to Munich to study at the Royal Academy of Arts and toured Italy to study the Renaissance style. On his return to Hungary, he formed a partnership with Mihály Pollack's son, Ágoston.

The architect originally designed his buildings in the Neoclassical style and later adopted the Romantic style. Finally, after his many study trips to Italy, he simplified his designs to bring a resemblance to the Renaissance style forms. Although traces of the Neo-Romanesque style still appear in his later buildings, after the second study trip to Italy in 1860 , he became interested in the possibility of revitalizing the Italian Renaissance, designing many Neo-Renaissance buildings. The Tuscan style - Quattrocento is to be found in the Margaret Island's Baths, a mature style of Palazzo Renaissance at the Corvinus University or at the Hungarian State Opera in Budapest, decorated with elements of Cinquecento style, and which stands out for its opulence and grandeur, but also through the building's plan and composition, thus playing an important role in the development of architecture in Hungary in the nineteenth century. Many of his buildings were determinant elements of urban planning in Budapest: Saint Stephen's Basilica (1867-1891), Rác Baths, former Palace of Customs (1871-1874), the throne room and Krisztinaváros wing of the Royal Palace.

Ybl's style can also be found in the churches and castles built in Transylvania, where the architect's work is less known and researched. One of the great Hungarian families in Transylvania, for which he worked, is the Csekonics family.

\section{Csitó Castle, Zsombolya (Jimbolia, Timiş county, Romania)}

The Csekonics family has Croatian roots. The first mention of the family dates from the sixteenth century. It had the original residence in Köszeg, western Hungary. The first family member to be ennobled was Pál (17 January 1753 - Baron of Zsombolya). His son, József Csekonics was a general of the Austro-Hungarian Army.

In 1784, József became commander of two imperial herds of horses, Mezőhegyes and Bábolna. On 11 December 
1800, he bought approximately 55,300 acres of land in Jimbolia (Zsombolya/Žombolj/Hatzfeld, Romania), where he organized a horse stud. Count József died in 1824.

In Jimbolia, the Csekonics family had two castles: one, the oldest, is found in the city and is still used today as the city hall; the second castle, built by János (the son of József) between 1869 and 1870, is Csitó Castle. The latter was built on the family's land bought in 1800 (Fig. 1). The Count's family used the castle (Fig. 2, Fig. 3) only during the summer, spending winters at their residence in Budapest (Szilágyi and Tufegdžić, 2014).

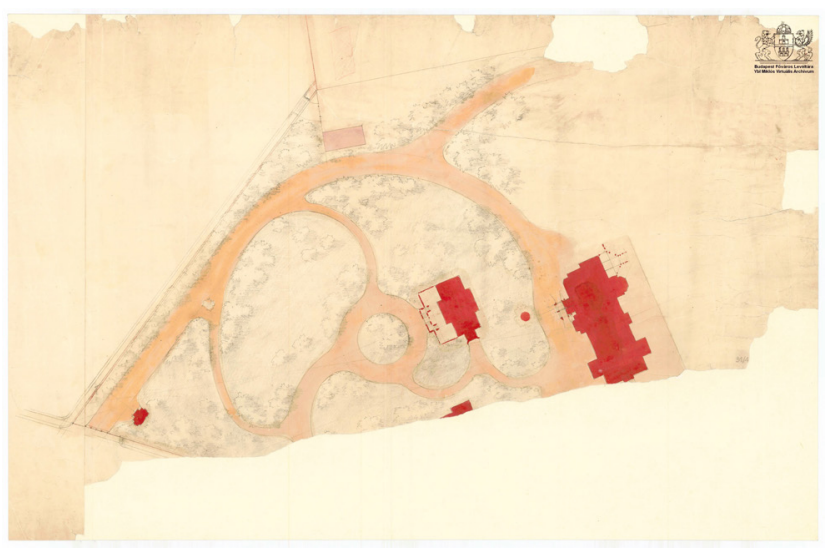

Fig. 1 The Csitó domain (plan) (Ybl, 1869)

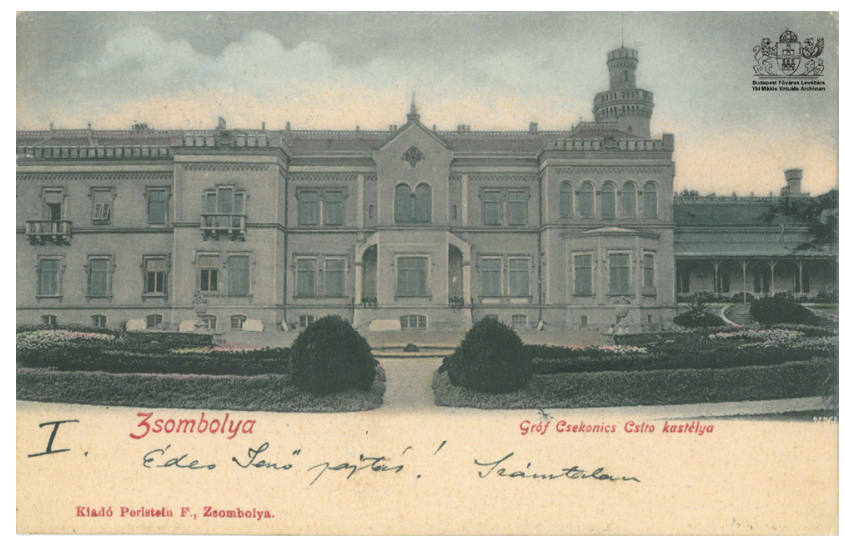

Fig. 2 The Csitó Castle's façade from a post card (Perlstein, around 1902)

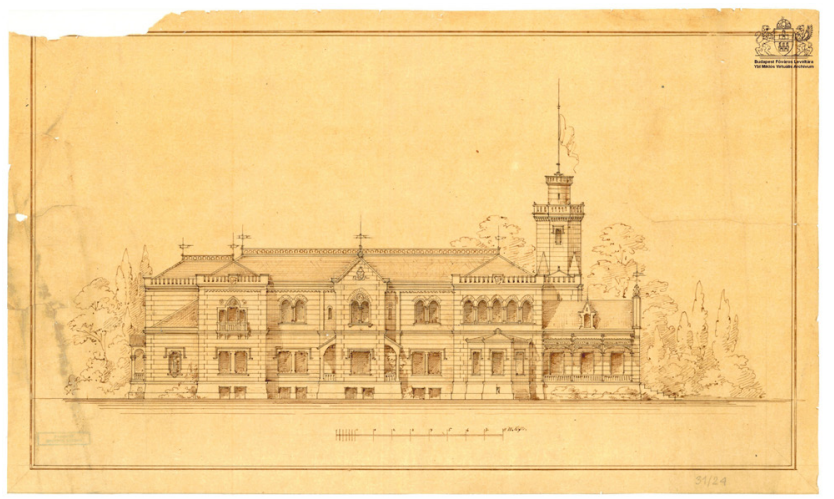

Fig. 3 The Csitó Castle's façade from Budapest Archives - Ybl legacy (Ybl, 1869)
Csitó Castle has a ground floor (Fig. 4) and first floor, having elements of Neo-Gothic style, it features a typical Anglo-Saxon Tudor style from the late Middle Ages. The massive building has a rectangular plan and a side tower with an octagonal plan. The main façade (Fig. 5) is divided by three jutting elements breaking the building's rectangular plan.

Ybl Miklós, who always tried to create a sense of harmony and balance in his projects, integrated an iconic feature into the castle's construction, namely a tower with an octagonal plan (Fig. 6). Its positioning is on the side of the building towards the main entrance and slightly withdrawn, which makes the building a little less massive. Some parts of the building and the top have a decorated belt element. The tower has a smaller diameter cylindrical construction on the upper level, resembling the main tower, and accentuating its verticality.

Ybl's style in space composition, which constitutes a modern living element, is the division, with minimal circulation, between apartments and the spaces to socialize. In terms of interior space division, this concept is often used in his other castle projects; another example is Károlyi Castle in Parádsasvár.

From the main entrance, the access to the two-level height main lobby and the circular galleries from upstairs is via one staircase. The dining room, food storage, and the countess's main salon that opened onto the garden could be accessed from this lobby. Through a small boudoir (smaller salon), the countess's apartment was reached. This apartment had rooms set in a row: a bedroom and a bathroom with dressing room. The ensemble's design, consisting of the countess's bathing room and bedroom, are characteristic elements of Ybl's style. After the countess's apartment, there were the children's rooms and living space for the

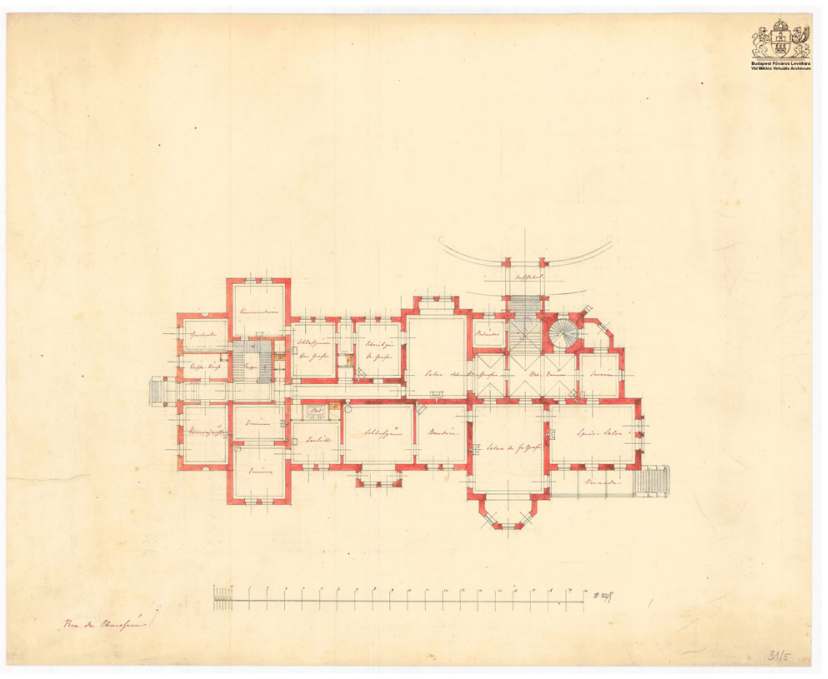

Fig. 4 The Csitó Castle's ground floor plan (Ybl, 1869) 


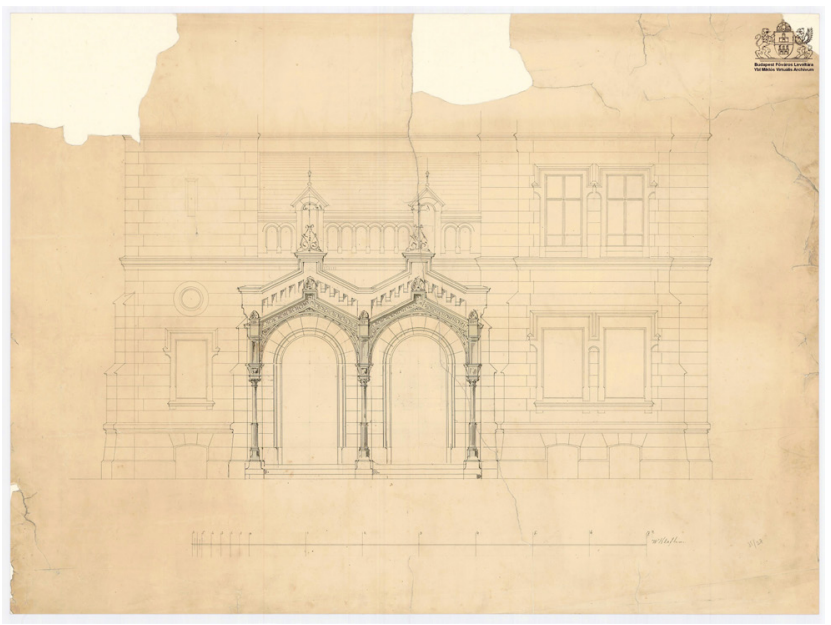

(a)

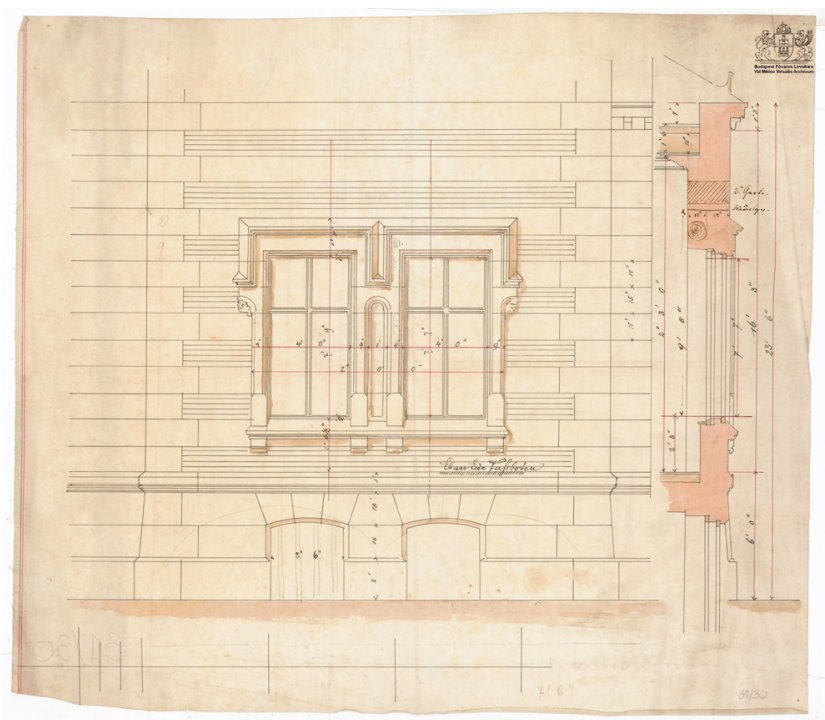

(b)

Fig. 5 Façade details: entrance and windows; (a) Detail of the northern facade of the castle with the entrance, incomplete; (b) Exterior view and section of a double window - (Ybl, 1869)

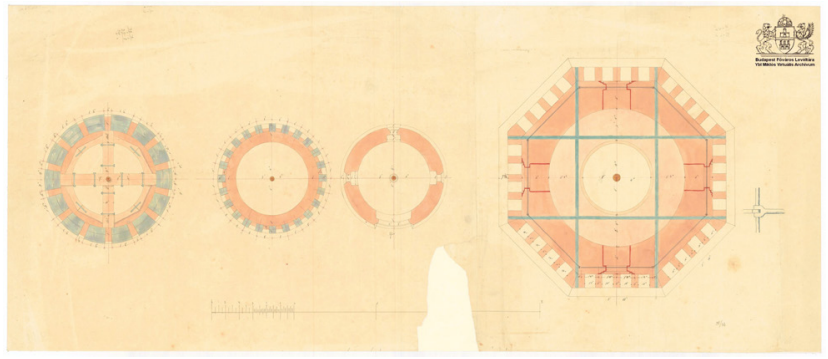

Fig. 6 The Csitó Castle's tower plans (Ybl, 1869)

countess's maid. The apartment of the countess was separated from that of the Count through a corridor. The architect put the two apartments on the same level to provide a direct connection in this space, but with a degree of personal privacy. The Count's apartment consisted of his salon, an office connected to the bedroom, which also had a dressing room. The bedroom had a direct connection to the butler's room and the servants' corridor. This design style created a nice living space while having a discreet servant circuit and separated to the main circulation. At the end of this servant's hallway, there is a small kitchen for coffee, and behind it was the family's wardrobe. The first floor is accessed through two staircases: one, monumental, connected with the central lobby and a second, smaller, gaining access from the servants' corridor.

The castle also had outbuildings, a separate kitchen, a shed for carriages, and stables.

In 1884, an extension was added - a chapel based on Meinig Arthur's plans. The chapel was fashioned in NeoGothic style and connected to the tower by a greenhouse. In 1900, opposite the chapel, another extension was constructed (with another six axes).

The Count's descendants experienced a period of financial difficulties, which resulted in the castle being dismantled in 1937 and sold piece by piece as building materials.

\section{The church, Franciscan monastery and mausoleum of Kaplony (Căpleni, Satu Mare County, Romania)}

A particularly important document that certifies the friendship of Count Károlyi György and Ybl Miklós is the written recommendation for the architect and his work carried out on 23 November, 1849. The letter is currently in the Hungarian National Gallery - Database Collection and declares that the architect, Ybl, has been in his service since 1843, during which he built the Kaplony church and the family's crypt and the reception hall of the Nagykároly castle.

The monument's ensemble from Kaplony (Fig. 7), located in the centre of the village, comprises three buildings: the church, the Franciscan monastery and the mausoleum from the eastern side of the church, used as a burial place for the Károlyi family's members. These buildings are located on a parcel of irregularly shaped land.

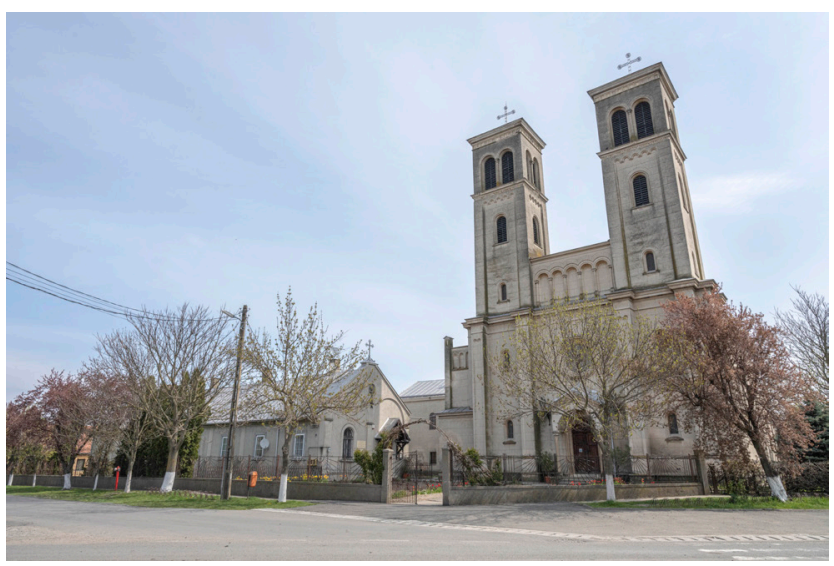

Fig. 7 The Kaplony ensemble (Popescu, 2021) 
This Franciscan church and the mausoleum are one of the first works of Ybl Miklós, designed without any other collaborators. At the same time, this ensemble is a late example of the architectural trend of the Romantic style characterized by the use of semicircular elements (Rundbogenstil) and Neo-Romanesque style. It can be considered a precursor of the most important ecclesiastical buildings of the Hungarian Romantic style: the Roman Catholic Church in Fót (Hungary), also built according to the plans of Ybl Miklós, between 1845 to 1855, commissioned by the Károlyi family.

Kaplony's first church and monastery were built in the eleventh century and belonged to the Benedictine monks. The first church dedicated to St. Martin was protected by the Kaplony families, which the Károlyi family was part of, and served as a burial place for the descendants.

The renovation of the church and the construction of a new monastery was initiated by Károlyi Sándor, who in 1711 gave these buildings to the Salvatorian Franciscans. Despite the church's restoration between 1711 and 1714, it did not undergo radical changes, keeping its medieval form until the early nineteenth century, when, after the 1834 earthquake, it was rebuilt according to the designs of the then renowned Budapest architect, Ybl Miklós. The reconstruction works of the church and the monastery took place between 1842 and 1848 with financial support from Count Károlyi György.

The church and new monastery, consecrated in 1848, received a new patron, St. Anthony of Padua. They were rebuilt mainly on the site of the Baroque buildings. This assumption is mainly because, when the church was rebuilt, Ybl reused the old Baroque church's walls, thus incorporating fragments of carved stones of the medieval church. In November 2012, a medieval window (from 1200) was found (A significant discovery in the Kaplony monastery) (Szakács, 2018).

Following these works, the building's plans have also suffered some changes; the basilica with three naves was converted by $\mathrm{Ybl}$ into a church hall type, with one wide nave featuring a panelled ceiling. Simultaneously, the choir acquired a new mausoleum with a Greek cross plan, which incorporated a Károlyi's crypt function situated, until then, under the chapel related to the South lateral nave of the church (Fig. 8).

The monastery was the worst affected by the earthquake; a vaulted corridor that bordered the patio on all sides, apart from its eastern side, still linking the monastery to the church today, collapsed entirely. Ybl Miklós renovated the damaged buildings, and instead of the southern

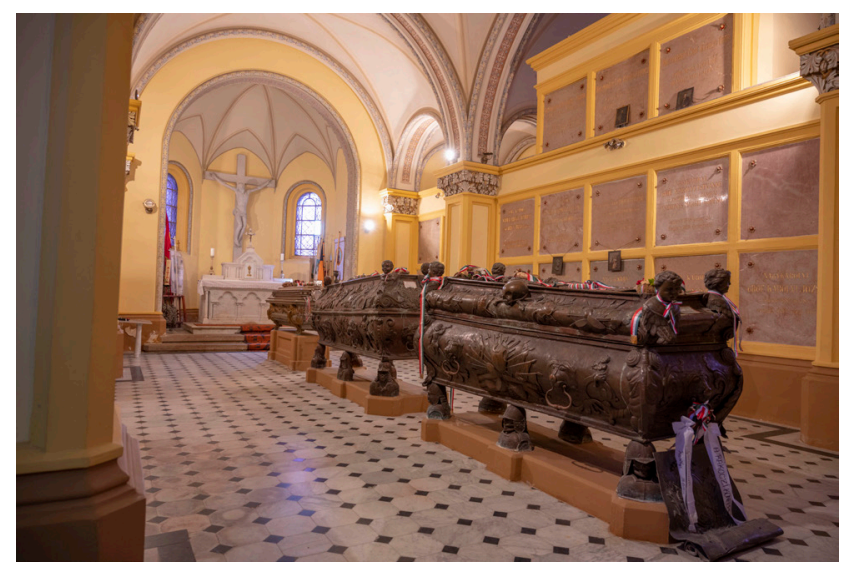

Fig. 8 The church's crypt (Popescu, 2021)

and western side of the monastery, he built a simpler building with only one floor in a T-shaped plan (Bara, 2010).

After the architect's works, the church and the Franciscan monastery have not suffered further significant interventions. Only the crypt was modified several times.

First, in 1892, with the support of Count Károlyi Tibor, it was renovated by the architect Meinig Artúr. Major changes occurred in 1904 when the family decided to move the burials into niches arranged in the walls. Following these reworks, the spaces between the pillars that separated the three naves of the mausoleum were walled with brick, and these niches were arranged for the remains of the Károlyi family members, each covered by a marble plate. Unfortunately, this intervention destroyed the three naves' space structure, and the windows lost their function.

The Franciscan church is a hall-type church, oriented east-west, with an internal semicircular apse on the eastern side and outdoor a rectangular closure, lined by a spiral staircase leading to a small platform. Here, on the right side of the altar, are the stairs that lead to the beautiful crypt founded after the apse.

The western side of the nave is articulated with two towers situated on each side of the church's main entrance located on the axis of the façade. Under these towers, there are two vestibules. On the left side of the vestibule is a small chapel dedicated to Our Lady of Lourdes, and on the right is a staircase leading to the space of the pipe organ.

To the northern side of the tower, a side chapel with an oratory upstairs has been attached. Based on the surveys made in the eighteenth century or by those made by Ybl Miklós of the Baroque church, we can assume that after the works he oversaw, the side chapel attached to the northern side of the nave was built, reusing the ruins of the southern side of the old cloister, in a way that on that floor an oratorio was built, accessible from the monastery. 
The material used for the church and mausoleum was brick, plastered both inside, and outside having artificial stone slabs.

The appearance of the western front of the church is determined by two towers without a crest, having a flat roof, and decorative elements evoking Romanesque style, such as rosette, blind arch, porch supported by columns and use of semicircular forms (Fig. 9).

The western façade of the church is divided horizontally by cornices into three levels. The first floor is backed up by three pillars that vertically divide the façade into three parts. The main entrance, which incorporates portal elements typical of Lombard Romanesque, is in the façade's axis.

The area between the two towers is marked by a decorative gazebo, articulated by a series of blind arcades, which rises above the nave.

Semicircular windows pierce the two lower floors of the towers, and the upper floor by twin semicircular windows, separated by columns with column heads decorated by acanthus leaves.

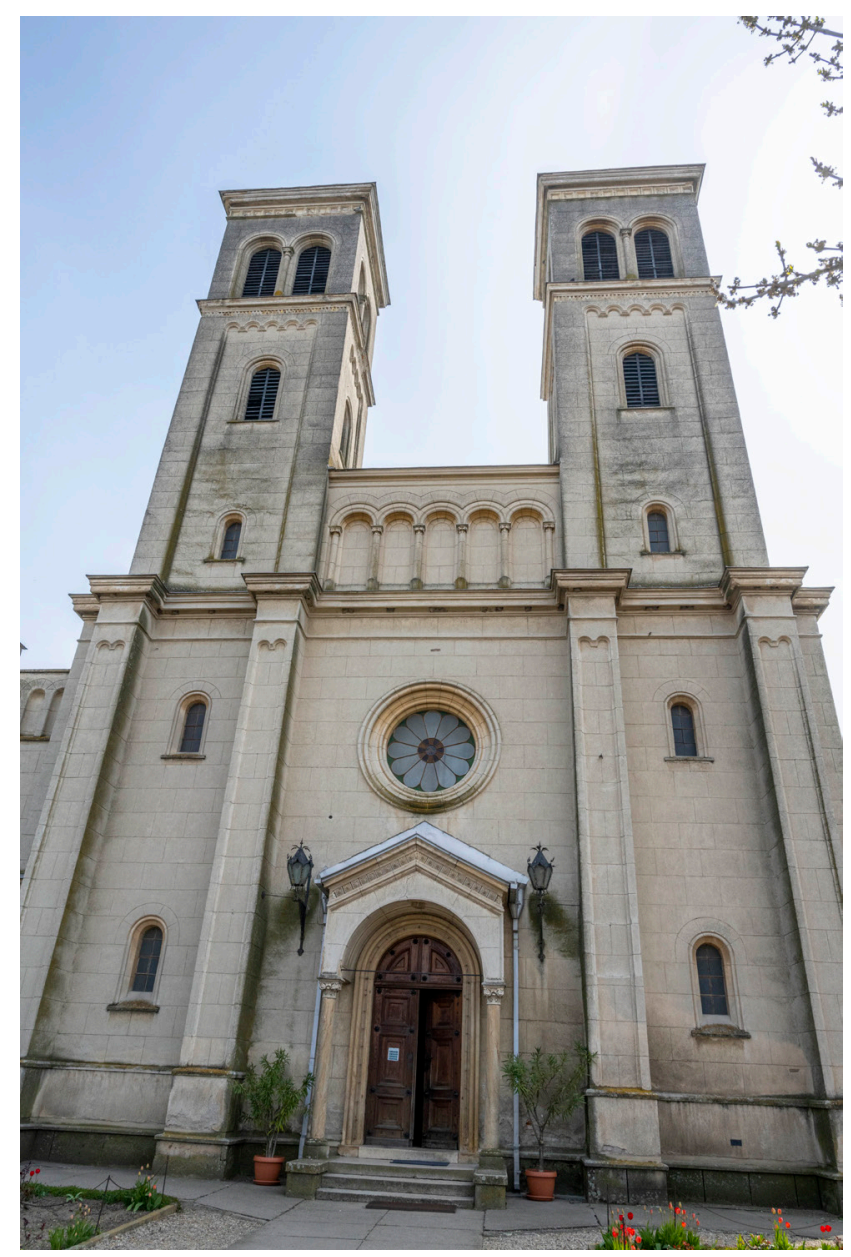

Fig. 9 The Kaplony cChurch (western façade) (Popescu, 2021)
The southern and northern aisles of the church are symmetrical on both sides of the central axis of the church, the nave's wall being articulated by semicircular windows divided into four parts (Fig. 10).

The interior is characterized by simplicity. The light in the nave is secured on both sides with four semicircular windows separated by semi-columns having composite capitals and windows decorated on the edges with stylized ornaments of stained glass.

The altar's apse is vaulted with a half-dome, and the nave has a flat ceiling; wooden panels decorated with floral ornaments (Fig. 11).

The entrance in the mausoleum is via a staircase located under the right and left side of the altar. It has a Greek cross plan with three naves and a polygonal choir. Initially, the naves were separated by columns with column heads decorated with acanthus leaves; the lateral walls of the naves and choir possessed larger windows. However, the mausoleum's original space is no longer perceptible due to the rehabilitation from 1904.

The mausoleum is covered with crossed vaults, while the choir has a star-shaped vault. The vaults and columns

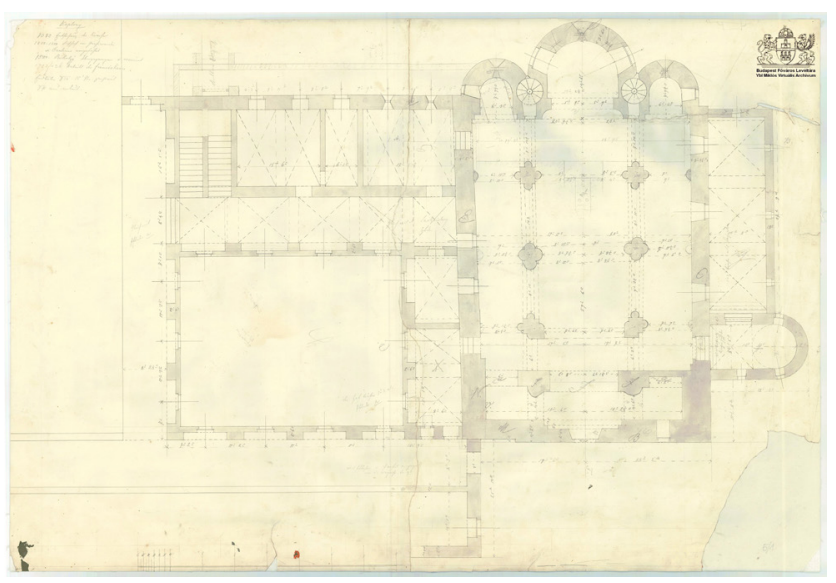

Fig. 10 Floor plan of the church and its annexed buildings (Ybl, 1841)

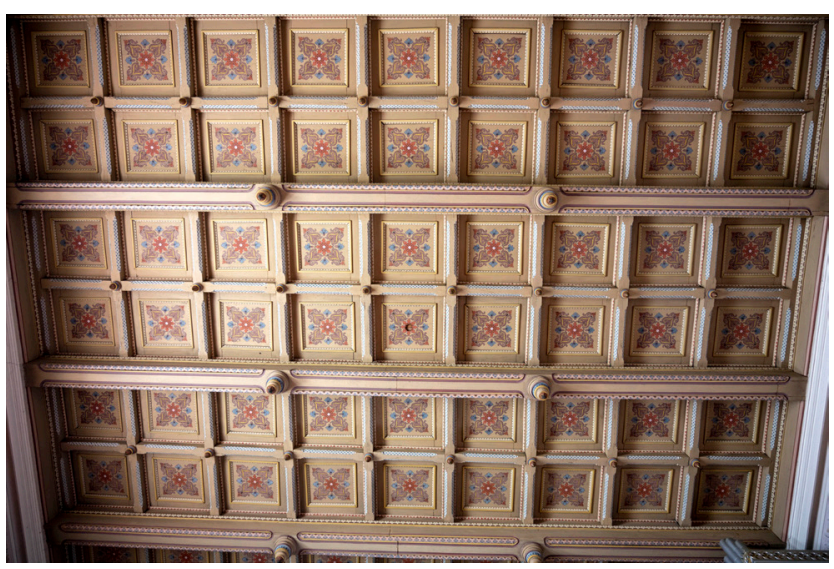

Fig. 11 The wooden panelled ceiling (Popescu, 2021) 
heads' lancets are decorated with various painted and gilded organic motives.

From the outside, the mausoleum's height is lower than the church's apse, being next to its west side. Due to the Greek cross plan and polygonal apse, its façades suggest a sort of dynamism. The walls are articulated with semicircular motifs, and the windows are similar to those of the church. In the areas where windows do not pierce the walls due to alterations, we can see blind semicircular windows.

On the eastern side of the cross's arms on both sides, there is a small semicircular niche, which we can only assume that initially they were intended to contain statues, but it is not ruled out that they may be simply decorative.

The monastery building has three wings. Their elevations are simple, without any decoration, apart from the wing attached to the church, whose façade was treated like that of the church.

The western part of the monastery is parallel to the street. On its southern side, there is the main entrance of the monastery. This part is T-shaped, linked with the section which is headed east. The latter is connected with the eastern part of the monastery, whose floor is linked to the church oratory.

\section{The ballroom of the Károlyi Castle from Nagykároly (Carei, Satu Mare County, Romania)}

Another project of Ybl Miklós is situated in Transylvania the Károlyi Castle from Nagykároly (Fig. 12). The Károlyi Castle from Nagykároly, Satu Mare, has an interesting history. It was built in the late fifteenth century and was an important part of the fortifications against the Turkish invasion.

The current appearance was acquired in 1894-1896 through work carried out under the supervision of the architect Meinig Arthur. The works were started by Károlyi Stephen, and the castle is built in an Eclectic style, with elements from medieval castles (Fig. 13).

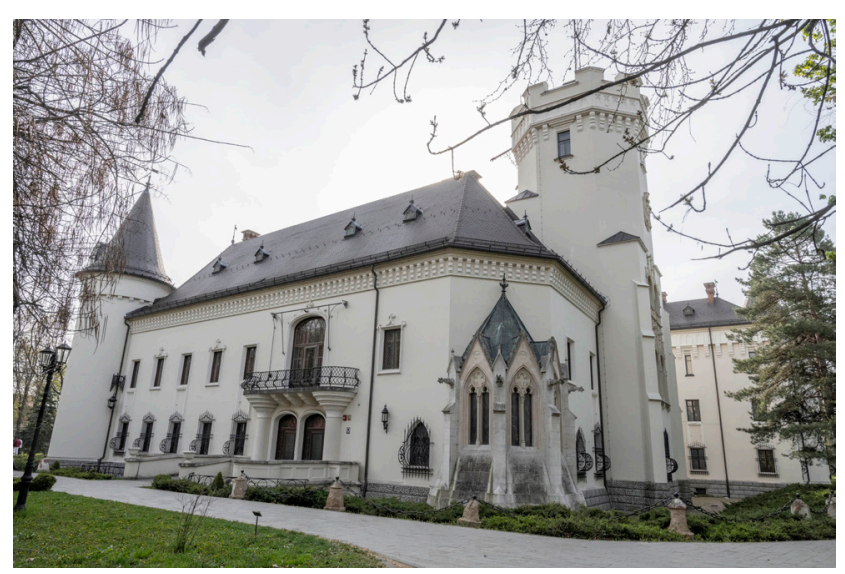

Fig. 12 The newly restored Károlyi Castle from Nagykároly (Popescu, 2021)

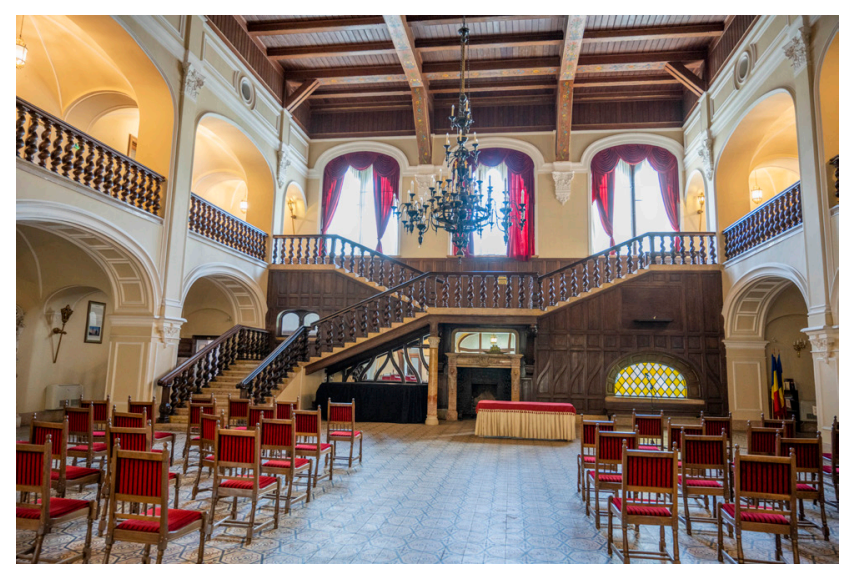

Fig. 13 The Károlyi Castle's Knight's room (Popescu, 2021)

In 1847, Ybl Miklós was asked to modify the castle, more precisely converting the ballroom area (Fig. 14). The ballroom of a noble residence represented the core of cultural life, both for the owner and the whole Hungarian aristocracy. Here were held several meetings having the most important political and cultural personalities, ambassadors and ministers, and aristocrats from all over Europe (Fekete, 2006; Popescu, 2014; Sisa, 2004).

Unfortunately, the works of the architect did not survive the passage of time; the castle was internally refurbished several times. Although a lost valuable design, it was recorded both in the documents and biographies of the architect (Fekete, 2006; Szilágyi, 2014).

\section{Conclusion}

Ybl Miklós, a leading figure of nineteenth-century architecture and famous architect, has rendered Hungarian architecture a heritage witness of history and having an undeniable value worthy of general recognition by UNESCO. Not by chance, in 2014, that the $200^{\text {th }}$ anniversary of the birth of Miklós Ybl was celebrated not only by Hungary but also by the whole UNESCO (UNESCO, 2014; UNESCO - Hungarian National Commission, 2014).

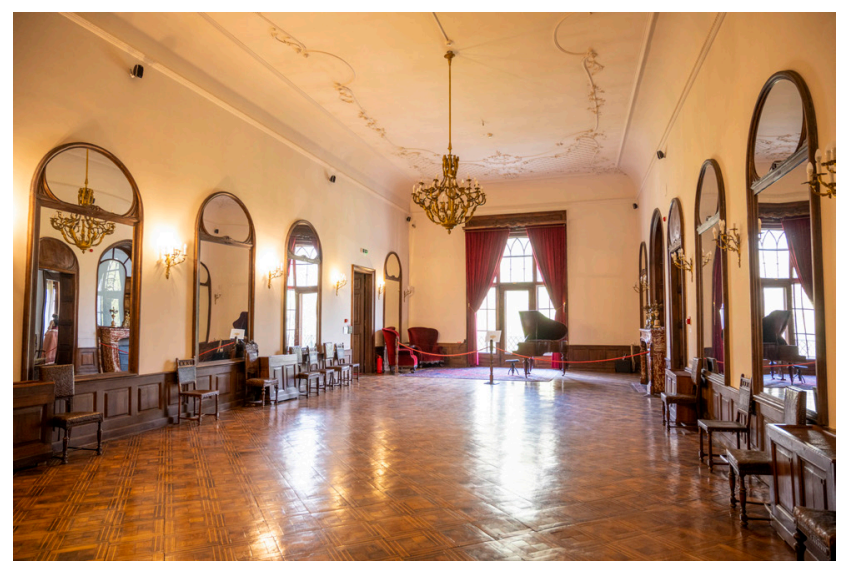

Fig. 14 The Károlyi Castle's ballroom (Popescu, 2021) 


\section{References}

Bara, J. (2010) "Páduai Szent Antal Ferences Templom és Rendház, Kaplony" (St. Anthony of Padua Franciscan Church and Monastery, Kaplony), Adatbank: erdélyi magyar elektronikus könyvtár, [online] 12 March 2010. (in Hungarian) Available at: http://lexikon.adatbank. transindex.ro/muemlek.php?id=249 [Accessed: 15 June 2021]

Count Károlyi, G., (1849) "Károlyi György gróf tanúsítványa Ybl Miklós számára" (Certificate from Count Károlyi György for Ybl Miklós, [letter], Hungarian National Gallery - Database Collection, 1692/1922, Related work: Roman Catholic Church and Mausoleum, Kaplony, Budapest City Archives, Budapest, Hungary. (in Hungarian)

Fekete, J. C. (2006) "Egy gondolat, két kastély: Zsombolya-Csitó, Ó-Kígyós" (One thought, two castles: Zsombolya-Csitó, Ó-Kígyós), Architectura Hungariae, 8(4). (in Hungarian) [online] Available at: http://arch.et.bme.hu/arch_old/korabbi_folyam/32/ fekete.html [Accessed: 15 June 2021]

Perlstein, F. (around 1902) "Föhomlokzat" (Main facade), [archive photo], Related work: Castle of Count Csekonics Endre, Zsombolya, Budapest City Archives- Postcard collection of Gerle János, HU BFL XIV.243, Budapest City Archives, Budapest, Hungary. (in Hungarian)

Popescu, M. (2014) "Two Hundred Years from the Birth of Arhitect Miklós YBL: Two of YBL's Works: One Destroyed and One Attributed", Transsylvania Nostra, 8(4), pp. 19-26. [online] Available at: http:// epa.niif.hu/03100/03141/00008/pdf/EPA03141_transsylvania_nostra_2014_4_019-026.pdf [Accessed: 20 June 2021]

Popescu, M. (2021) "The Kaplony ensemble", [digital photograph], Mara Popescu's personal archive.

Popescu, M. (2021) "The church's crypt", [digital photograph], Mara Popescu's personal archive.

Popescu, M. (2021) "The Kaplony church (western façade)", [digital photograph], Mara Popescu's personal archive.

Popescu, M. (2021) "The wooden panelled ceiling", [digital photograph], Mara Popescu's personal archive.

Popescu, M. (2021) "The newly restored Károlyi Castle from Nagykároly", [digital photograph], Mara Popescu's personal archive.

Popescu, M. (2021) "The Károlyi Castle's Knight's room", [digital photograph], Mara Popescu's personal archive.

Popescu, M. (2021) "The Károlyi Castle's ballroom", [digital photograph], Mara Popescu's personal archive.

Sisa, J. (2004) "Kastélyépítészet és kastélykultúra Magyarországon a historizmus korában" (Castle architecture and castle culture in Hungary in the age of historicism), PhD Thesis, Hungarian Academy of Sciences. (in Hungarian) Available at: http://real-d. mtak.hu/83/1/Sis.pdf [Accessed: 25 November 2015]

Szakács, B. Z. (2018) "Jelentős felfedezés a kaplonyi rendházban" (A significant discovery in the Kaplony monastery), In: Rozsnyai, J. (ed.) Ybl és Lechner vonzásában, Holnap, Budapest, Hungary, 2018, pp. 13-25. [online] Available at: http://nagykaroly.szatmar. ro/Jelentos_felfedezes_a_kaplonyi_rendhazban/hirek/41068\&cat_id $=222$ [Accessed: 25 November 2015]
Szilágyi, M. (2014) "A Nagy Háború következményei a Csekonicsuradalomban és annak épületállományában" (Consequences of the Great War in the Csekonics estate and its building stock), Létünk, 44(virtual section), pp. 131-152. (in Hungarian) [online] Available at: http://www.letunk.rs/a-nagy-haboru-kovetkezmenyei-a-csekonics-uradalomban-es-epuletallomanyaban/ [Accessed: 25 November 2015]

Szilágyi, M. A., Tufegdžić, A. (2014) "Zaboravljeno nasleđe: Graditeljsko nasleđe imanja Žombolj porodice Čekonjić / Elfeledett örökség: A Csekonics család zsombolyai uradalmának épített öröksége / Vergessenes Erbe: Das Bauerbe des Csekonics-Gutes in Hatzfeld", (Forgotten Heritage: The built heritage of the Csekonics family's estate in Zombolya), Univerzitet u Novom Sadu, Novi Sad, Serbia, pp. 166-123. (in Serbian, Hungarian, German)

UNESCO (2014) "Anniversaries celebrated by Member States Celebration of anniversaries in 2014)", [online] Available at: http:// www.unesco.org/new/en/unesco/events/prizes-and-celebrations/ celebrations/anniversaries-celebrated-by-member-states/2014/ [Accessed: 20 June 2021]

UNESCO - Hungarian National Commission's website (2014) "Celebration of Ybl Miklos", [online] Available at: http://www. unesco.hu/kultura/ybl-miklos-unesco/ybl-miklos-lechner-odon [Accessed: 25 November 2015]

Ybl, M. (1841) "A templom és a hozzá csatlakozó épületek földszinti alaprajza" (Ground floor plan of the church and adjoining buildings), [blueprint], Related work: Roman Catholic Church and Mausoleum, Kaplony, Budapest City Archives, Ybl legacy Collection, HU BFL XV.17.f.331.b - 5/1, Budapest City Archives, Budapest, Hungary. (in Hungarian)

Ybl, M. (1869-1870) "Végleges helyszínrajz a kastéllyal és a konyhával, hiányos" (Final site plan with castle and kitchen, incomplete), [blueprint], Related work: Castle of Count Csekonics Endre, Zsombolya, Budapest City Archives, Ybl legacy Collection, HU BFL XV.17.f.331.b - 31/4, Budapest City Archives, Budapest, Hungary. (in Hungarian)

Ybl, M. (1869-1870) "A kastély déli homlokzata" (The southern facade of the castle), [blueprint], Related work: Castle of Count Csekonics Endre, Zsombolya, Budapest City Archives, Ybl legacy Collection, HU BFL XV.17.f.331.b - 31/24, Budapest City Archives, Budapest, Hungary. (in Hungarian)

Ybl, M. (1869-1870) "A kastély tornyának négy különböző vízszintes metszete, hiányos" (Four different horizontal sections of the castle tower, incomplete), [blueprint], Related work: Castle of Count Csekonics Endre, Zsombolya, Budapest City Archives, Ybl legacy Collection, HU BFL XV.17.f.331.b - 31/14, Budapest City Archives, Budapest, Hungary. (in Hungarian)

Ybl, M. (1869-1870) "Kastély északi homlokzatának részlete a bejárattal, hiányos" (Detail of the northern facade of the castle with the entrance, incomplete) [blueprint], Related work: Castle of Count Csekonics Endre, Zsombolya, Budapest City Archives, Ybl legacy Collection, HU BFL XV.17.f.331.b - 31/27, Budapest City Archives, Budapest, Hungary. (in Hungarian) 
Ybl, M. (1869-1870) "Kettős ablak külső nézete és metszete" (Exterior view and section of a double window), [blueprint], Related work: Castle of Count Csekonics Endre, Zsombolya, Budapest City Archives, Ybl legacy Collection, HU BFL XV.17.f.331.b - 31/30, Budapest City Archives, Budapest, Hungary. (in Hungarian)
Ybl, M. (1869-1870) "Földszinti alaprajzi változat" (Ground floor plan), [blueprint], Related work: Castle of Count Csekonics Endre, Zsombolya, Budapest City Archives, Ybl legacy Collection, HU BFL XV.17.f.331.b - 31/5, Budapest City Archives, Budapest, Hungary. (in Hungarian) 